\title{
Koronakevät, omaehtoisuus ja uusi maailmaansuuntautuminen
}

\author{
Antti Lindfors ja Heidi Haapoja-Mäkelä
}

$\mathrm{V}$ uosikymmen 2020 toi mukanaan maailmanlaajuisen pandemian ja Elorelle uudet päätoimittajat. Me, Antti Lindfors ja Heidi Haapoja-Mäkelä, olemme molemmat Helsingin yliopiston tutkijatohtoreita ja pitkän linjan elorelaisia, joille lehden luotsaaminen seuraavan kahden vuoden ajan on miellyttävä ja haastava kunnia-asia. Uusina päätoimittajina koemme luonnollisesti velvollisuudeksemme ylläpitää Eloren tieteellistä tasoa ja tärkeää julkaisutoimintaa kansallisilla kielillä mutta myös viedä lehteä eteenpäin kohti uuden vuosikymmenen perinteen- ja kulttuurintutkimuksellisia (kuin myös yliopisto- ja julkaisupoliittisia) haasteita, mitä ikinä ne ovatkaan. Kaikeksi onneksi Elore on jo pitkään ollut edelläkävijänä edistämässä suomalaista tiedejulkaisemisen avoimuutta, joten emme joudu monien muiden lehtien tapaan miettimään uudelleen esimerkiksi open access -politiikkaamme, vaan pääsemme jatkamaan hyväksi havaitulta pohjalta. Edeltäjillemme Niina Hämäläiselle ja Nika Potinkaralle kiitokset evästyksestä vastuulliseen tehtävään!

Kulunut kevät on ollut kaiken kaikkiaan inmeellinen. Tieteellisten lehtien toimintaa koronavirus ei ole pysäyttänyt, eikä toivottavasti tule pysäyttämäänkään. Tätä pääkirjoitusta kesäkuun alussa kirjoitettaessa koronapandemian ensimmäinen aalto on Suomessa hiipumassa, mutta sen kulttuurisista (ja taloudellisista, poliittisista, psykologisista jne.) seurausvaikutuksista monet ovat jo nähtävissä, ja yhä useammat jäävät vielä arvausten varaan. Folkloristeille ja muille kulttuuria, viestintää ja vuorovaikutusta tutkiville korona onkin nostanut esiin monia tutkimuksellisesti huomionarvoisia ilmiöitä ja tapahtumaketjuja. Ne ovat olleet yhtä lailla kansainvälisiä ja verrattain odotettavia, liittyen esimerkiksi tiettyjen ilmaisullisten muotojen tulvaan sosiaalisessa mediassa, kuin myös paikallisia ja melko odottamattomia, kuten uusimaalaisen identiteetin esiinnousu keväisen eristyksen aikaan. Yksi viruksen merkittävimmistä ja pitkäkestoisimmista vaikutuksista liittyy kuitenkin sosiaalisen etäisyyteen (social distancing), sen mukanaan tuomaan "digiharppaukseen" ja kokonaiseen maailmaansuuntautumisen uudelleenkalibrointiin, jonka myötä erilaisiin kontakteihin, kanaviin ja esineisiin on syytä suhtautua mahdollisina viruksen kantajina ja välittäjinä. Korona on tästä näkökulmasta suuri fyysisten, diskursiivisten ja sosiaalisten kontaktien testikenttä, joka on kliseetä uhmaten näyttänyt meille jotain uutta (ihmis)kontaktien merkityksestä - viedessään ne pois. 
Ihmiskontakti ei ole merkityksellinen vain affektiivisen tai psykologisen hyvinvoinnin mielessä, vaan yhdenlainen semioottinen eli merkkivälitteinen resurssi, joka asettuu erilaisissa kulttuurisissa viitekehyksissä erilaiseen valoon. Tarkastellessaan blogikirjoituksessaan koronapandemian vaikutuksia nimenomaan ihmiskontaktien kulttuuriseen semiotiikkaan lingvisti-antropologit Luke Fleming ja James Slotta esittävät, kuinka koronan mukanaan tuomat välttelykäytännöt ovat synnyttäneet omanlaisensa viestinnällisen rekisterin. Tätä rekisteriä voitaisiin käsillä olevaa Eloren teemanumeroa mukaillen nimittää vernakulaariksi eli omaehtoiseksi hybridiksi (ks. Koski \& Turtiainen, tässä numerossa). Siinä institutionaaliset ohjeet saavat tilanteisen ja paikallisen muodon, jolla viestitään paitsi pelonsekaisia ennakkoluuloja ja sosiaalisia hierarkioita ("Älä tule lähemmäs, senkin uusimaalainen!") myös huomioimista, läheisyyttä ja huolenpitoa ("En vieraile isovanhemmillani, koska en halua tartuttaa heitä").

Pandemian esteettisiä aspekteja paikantaessaan Jozef Kovalčik ja Max Ryynänen (2020) nostavat esiin kahdeksan huomion arvoista ilmiötä kasvomaskien normalisoitumisesta (tiettyjen Aasian maiden ulkopuolellakin) kapitalismin rytmimuutoksiin ja funktion nousuun estetiikan ohi ja yli (mikä taas tuottaa uutta funktion estetiikkaa). Näihin teemoihin voisi lisätä sen vernakulaarin ilmaisun, estetiikan ja arkikäytäntöjen kentän, jonka ilmenemismuotoja ja rajoja korona on provosoinut, muokannut, mahdollistanut tai kaventanut. Samoin niihin kytkeytyvät ne moninaiset tulkintakehikot, joiden kautta koronapandemiaa on poliittisesti, moraalisesti ja idealistisesti merkityksellistetty (esimerkiksi väistämättömän ilmastokatastrofin esinäytöksenä, luonnon ja ei-inhimillisen toimijuuden lähettämänä varoituksena, globaalin salaliiton juonena, jne.). Muun muassa näiden ilmiöiden tarkasteluun nyt julkaistavasta Elore-numerosta, joka avaa neljä erilaista näkökulmaa vernakulaarin kulttuurin käsitteellistyksiin, on toivottavasti apua.

Tämän numeron vastaavina toimittajina ovat Outi Fingerroos, Niina Hämäläinen ja Ulla Savolainen. Kiitämme heitä sujuvasta yhteistyöstä ja toivotamme lukijoillemme virikkeellisiä lukuhetkiä.

\section{Lähteet}

Fleming, Luke \& Slotta, James 2020. Social Distancing and the Cultural Semiotics of Contact. Society for Linguistic Anthropology -blogi. Saatavilla: http://linguisticanthropology.org/ social-distancing-cultural-semiotics-contact/?fbclid=IwAR3icUlZb6X1SdWAg2r-iDWk mr1r9sfMBwpSHxbyoQs10nGPhcnsUwAjTRo.

Kovalčik, Jozef \& Ryynänen, Max 2020. Gazing at the invisible: How can aesthetic theory help make sense of the state of emergecy initiated by Covid-19? Popular Inquiry: The Journal of Aesthetics of Kitsch, Camp and Mass Culture Volume 2/2020. Saatavilla: https:// www.popularinquiry.com/blog/2020/4/9/jozef-kovalik-and-max-ryynnen-gazing-atthe-invisible-how-can-aesthetic-theory-help-make-sense-of-the-state-of-emergencyinitiated-by-covid-19.

Antti Lindfors (FT) on Helsingin yliopiston folkloristiikan post doc -tutkija. Hän on kirjoittanut väitöskirjansa stand up -komiikasta ja aloittelee paraikaa Suomen Akatemian 
rahoittamaa kolmivuotista projektiaan "Itsen kehittämisen etiikka ja somaestetiikka nykypäivän biohakkeroinnissa" (2020-2023). Vapaa-ajallaan hän maadoittuu Paimion metsissä.

Heidi Haapoja-Mäkelä (FT, MuM) on folkloristiikan post doc -tutkija, joka työskentelee Helsingin yliopistossa Koneen säätiö rahoittamassa "Omistajuus, kieli, kulttuuriperintö - kansanrunousideologiat Suomen, Karjalan tasavallan ja Viron alueilla" -projektissa. Vapaa-ajallaan hän soittelee nokkahuiluja, hoitaa huonekasveja ja laulaa keskiajan ja renessanssin kuoromusiikkia. 